Indonesian Journal of Biotechnology, December, 2011

Vol. 16, No. 2, pp.93-99

\title{
Molecular Identification of Lactic Acid Bacteria Producing Antimicrobial Agents from Bakasang, An Indonesian Traditional Fermented Fish Product
}

\author{
Helen Joan Lawalata ${ }^{1^{*}}$, Langkah Sembiring ${ }^{2}$, and Endang Sutriswati Rahayu ${ }^{3}$ \\ ${ }^{1}$ Departement of Biology, Faculty of Mathematics and Natural Science, Manado State University, \\ Manado, Indonesia \\ ${ }^{2}$ Faculty of Biology, Universitas Gadjah Mada, Yogyakarta, Indonesia \\ ${ }^{3}$ Faculty of Agricultural Technology, Universitas Gadjah Mada, Yogyakarta, Indonesia
}

\begin{abstract}
Twenty seven strains of lactic acid bacteria (LAB) were isolated from bakasang, Indonesian traditional fermented fish product. In general, LAB have inhibitory activity againts pathogenic bacteria and spoilage bacteria. Screening for antimicrobia activity of isolates were performed with well-diffusion method. One isolate that was designed as Pediococcus BksC24 was the strongest against bacteria pathogenic and spoilage bacteria. This strain was further identified by $16 \mathrm{~S}$ rRNA gen sequence comparison. Isolates LAB producing antimicrobial agents from bakasang were identified as Pediococcus acidilactici.
\end{abstract}

Keywords : Bakasang, LAB, antimicrobial, phenotypic characteristics, 16S rRNA gene

\section{Introduction}

Bakasang is fermented fish products traditionally made from the guts of big fish (Katsuwonus pelamis L.), small fish and fish eggs which is the typical food of North Sulawesi (Manado). In fermented food fish, Lactic Acid Bacteria (LAB) is a bacterium which played important role in the process of fermentation. One role of lactic acid bacteria is the ability to produce antimicrobial components that can inhibit the growth of pathogenic bacteria and spoilage bacteria. Components that are antagonistic can be found in the form of organic acid, hydrogen peroxide, and diasetil bacteriocin (Daeschel,1989; Ouwehand,1998; Park et.al., 2005). Natural antimicrobial produced by lactic acid bacteria have been widely used as chemotherapeutic agents that can control the growth of pathogenic microbes (Liasi et

*Correspondence author:

Helen Joan Lawalata

Departement of Biology, Faculty of Mathematics and Natural Science, Manado State University, Kampus UNIMA Tondano. Indonesia.

Email: lawalata_helen@yahoo.com al.,2009). LAB included as safe microorganisms when added to food because its not toxic and does not produce toxin, so-called foodgrade microorganisms and are designated as "Generally Recognized as Safe" (GRAS). These microorganism is not at risk to health, even some types of bacteria are useful for health. In Indonesia, it has been widely reported data that revealed the potential of lactic acid bacteria as producers of antimicrobial substances from fermented foods (Savadogo, 2004; De Vuyst and Vandamme, 1994). The objectives of the experiment was to isolate and identify lactic acid bacteria on bakasang (fermented Cakalang fish) and to test the inhibitory activity against pathogenic bacteria and spoilage bacteria by using well-diffusion method.

\section{Material and Methods}

Indicator Strains and Growth Conditions Escherichia coli ATCC 35218 and Stapylococcus aureus ATCC 25923 were obtained from the collection of Laboratory of Microbiology, Faculty of Medicine, Universitas Gadjah Mada, while Pseudomonas fluorescens FNCC 0070 and Pediococcus acidilactici PAF 
11 were obtained from the collection of Laboratory of Microbiology, Center for Food and Nutrition, Universitas Gadjah Mada. All strain, except Pediococcus acidilactici PAF 11, were grown in NA (Nutrien Agar) at $37^{\circ} \mathrm{C}$.

Pediococcus acidilactici PAF 11 (positive control) was grown in De Man Rogosa Sharpe (MRS) at $37^{\circ} \mathrm{C}$.

\section{Isolation of Lactic Acid Bacteria}

Guts of Big fish, and egg fish were collected from local market in Manado. These samples were transported to the laboratory using cool box $\left(4^{\circ} \mathrm{C}\right)$ and cut into small pieces and mashed. Salt and rinse reagent were added and mix thoroughly. The mixture was packed into bottles, corked and then incubated at $37^{\circ} \mathrm{C}$ for 7 days. LAB were isolated from sample of bakasang. Ten grams of samples were taken aseptically and homogenized in $90 \mathrm{~mL}$ of $\mathrm{NaCl}$ solution. Serial dilutions up to $10^{-7}$ were prepared and appropriate dilutions were plated onto de Man Rogosa and Sharpe Agar supplemented with $\mathrm{CaCO}_{3} 1 \%$, Na Azida and cyclohexamide. All plates were incubated at $37^{\circ} \mathrm{C}$ for $48 \mathrm{~h}$. Only lactic acid producing bacterial colonies were selected. This can be observed from clear zones around the colonies which indicated the dissolving of $\mathrm{CaCO}_{3}$ by an acid. Colonies with different morphology were counted, picked up and purified by restreaking on the same medium.

Cell morphology, Gram staining and catalase test, motility, non-spore forming were performed as a preliminary screening for lactic acid bacteria (Holt et al, 1994). The selected lactic acid bacteria were maintained as stock cultures at $-80{ }^{\circ} \mathrm{C}$ in $10 \%$ skim milk and $20 \%$ glycerol.

\section{Screening of Lactic Acid Bacteria for Antimicrobial Activity}

The antimicrobial activity of LAB (Culture) against Escherichia coli ATCC 35218, Stapylococcus aureus ATCC 25923, 0070, Pseudomonas fluorescens FNCC 0070 was performed by the well diffusion assay (Davidson and Paris, 1989). Lactic acid bacteria culture were grown in MRS broth at $37^{\circ} \mathrm{C}$ for $24 \mathrm{~h}$. Indicator bacteria were grown in Nutrien Broth at $37^{\circ} \mathrm{C}$ for $24 \mathrm{~h}$. Ten mililiters of Nutrien soft agar was inoculated with $50 \mu \mathrm{l}$ broth culture of pathogenic bacteria. MRS agar was poured on petri dish and allow to solidify, then overlaid with nutrient broth prepared previously and then incubated at $4^{\circ} \mathrm{C}$ for $1 \mathrm{~h}$. Wells were made and filled with $50 \mu \mathrm{LAB}$ culture Incubation petri dish at $37^{\circ} \mathrm{C}$ for $24 \mathrm{~h}$. LAB isolates which gave clear zones are indicated as isolates that have antimicrobial activity against indicator bacteria. The diameter of the inhibition zone was measured. The antimicrobial activity was determined by measuring the clear zone around the wells.

\section{Identification of Lactic Acid Bacteria Isolates}

The isolated LAB showing the highest antimicrobial activity were identified based on phenotypic and genotypic characterization. Phenotypic characterization was performed by examining cell morphology, motility and spore forming of isolate. Isolate was Gram stained and tested for catalase production, and were preliminarily identified based on the phenotypic properties such as gas production from glucose, growth at different temperatures as well as the ability to grow in different concentrations of sodium chloride and $\mathrm{pH}$ in De Man, Ragosa, Sharpe (MRS) broth (Dykes et al., 1994). Genotypic characterization was conducted by $16 \mathrm{~S}$ rDNA sequence comparison.

\section{Genomic DNA Extraction}

Extraction of genomic DNA were done as described by Pospiech and Neumann (1995) with minor modifications to the method versatile quick prep for gram positive bacteria. Bacteria were cultivated on MRS broth. After 2-3 days of cultivation at $30^{\circ} \mathrm{C}, 1.5 \mathrm{~mL}$ of biomass was collected by centrifugation ( $5 \mathrm{~min}, 13.000 \mathrm{rpm}$ ). The pellet was resuspended in $400 \mu \mathrm{LSET}$ buffer $(75 \mathrm{mM}$ $\mathrm{NaCl}, 25 \mathrm{mM}$ EDTA, $20 \mathrm{mM}$ Tris, $\mathrm{pH}$ 7,5), 50 $\mu \mathrm{L}$ Lysozyme (10 mg/mL), $20 \mu \mathrm{L}$ Proteinase 
$\mathrm{K}(15 \mathrm{mg} / \mathrm{mL})$ were added and incubated at $37^{\circ} \mathrm{C}$ for $1 \mathrm{~h}$. Fifty microliters SDS $10 \%$ was added and incubated at $65^{\circ} \mathrm{C}$ for $1 \mathrm{~h}$. $400 \mu \mathrm{L}$ cooled chloroform was added and centrifuged (13.000 rpm $10 \mathrm{~min})$. The aqueous layer was re-extracted with isopropanol (1:1 $\mathrm{v} / \mathrm{v}$ ) and then incubated at $-20^{\circ} \mathrm{C}$ overnight. DNA was centrifugated and washed with cooled ethanol $70 \%$ and then supernatant was removed. The purify of DNA solution was resuspended with TE buffer and checked spectrophotometrically at $\lambda_{260}$ and $\lambda_{280} \mathrm{~nm}$.

\section{Amplification and Sequencing 165 rDNA}

The 16S rRNA genes were amplified from purified DNA of the strain using a commercial kit (Mega Mix Blue ${ }^{\circledR}$ and universal primers 27f (5'-AGAGTTTAGTCCTGGCTCAG-3') and 1492r (5'-GGTTACCTTGTTACGACTT-3') for 16S rDNA (Thomas, 2007). The condition of amplified gene fragment : pre-denaturation of the target DNA at $96^{\circ} \mathrm{C}$ for $4 \mathrm{~min}$ followed by 30 cycles at $94^{\circ} \mathrm{C}$ for $1 \mathrm{~min}$, primer annealing at $51,5^{\circ} \mathrm{C}$ for $1 \mathrm{~min}$ and $30 \mathrm{sec}$ and primer extension at $68^{\circ} \mathrm{C}$ for $8 \mathrm{~min}$. PCR was completed with $10 \mathrm{~min}$ elongation at $68^{\circ} \mathrm{C}$ followed by cooling to $4^{\circ} \mathrm{C}$. PCR product was visualised by electrophoresis on a $2 \%(\mathrm{w} / \mathrm{v})$ agarose gels, stained with ethidium bromide in the presence of a $1 \mathrm{~kb}$ ladder The parameters for the electrophoresis were $90 \mathrm{~V}$ for $30 \mathrm{~min}$.

The amplified of DNA fragments were sequenced using sequencer model ABI 3100 sequencer according to manufacturers'instructions (ABI PRISMA 3100 Genetic Analyzer User's Manual).

\section{Phylogenetic analysis}

For phylogenetic analysis, sequences BksC24 strain and BksJ43 strain were aligned by using CLUSTAL X software (Thompson, 1997). The phylogenetic tree of the $16 \mathrm{~S}$ rDNA sequences was constructed by the neighborjoining algoritm (Saitou, and Nei, 1987). The root position on the unrooted tree was estimated by using Bacillus subtilis DSM 10 as the outgroup strain.

\section{Results and Discussion \\ Isolation of Lactic Acid Bacteria}

Samples of bakasang were used for isolation of lactic acid bacteria. 45 isolates of LAB in which production clear zone around theirs colonies were obtained from bakasang. The clear zone appearance is due to the dissolution of $\mathrm{CaCO}_{3}$ on MRS medium by acid agent (Panthavee et al., 2007). Among the 45 isolates were rearranged and confirmed as LAB 27 isolates. All of these isolates were Gram positive, rods and cocci, appeared singly, in pair, chain, tetrad. Cell were non motile and non spore forming and gave negative reaction for catalase. These strains were then classified into genus level using profile matching method. Based on the profile matching method these 27 isolates separated into three groups.

Table 1. Identification of lactic acid bacteria isolates into genera level by profile matching method.

\begin{tabular}{|c|c|c|c|c|c|c|}
\hline & \multicolumn{6}{|c|}{ Group } \\
\hline Characteristics & I & II & III & Lactobacillus $^{*}$ & Pediococcus $^{*}$ & Leuconostoc* \\
\hline Number of isolates & 5 & 16 & 6 & & & \\
\hline Gram stain & + & + & + & + & + & + \\
\hline Shape & Rods & Cocci & Cocci & Rods & Cocci & Cocci \\
\hline Cell arrangement & Single/pair/chain & Tetrad & Pair/chain & Single/pair/chain & Tetrad & Pair/chain \\
\hline $\begin{array}{l}\text { Production gas from } \\
\text { glucose }\end{array}$ & $+/-$ & - & + & $+/-$ & - & + \\
\hline Catalase & - & - & - & - & - & - \\
\hline Spore formation & - & - & - & - & - & - \\
\hline Motility & - & - & - & - & - & - \\
\hline Fermentation type & Hetero/homo & Homo & Hetero & Hetero/homo & Homo & Hetero \\
\hline
\end{tabular}

+positive reaction or growth; - no reaction or no growth 
Group I were putatively identified as genus Lactobacillus. Group II were represented as cocci (tetrad) homofermentative which were identified as genus Pediococcus. Finally, group III were identified as genus Leuconostoc. It was concluded that lactic acid bacteria isolated from bakasang are dominated by Lactobacillus, Pediococcus, and Leuconostoc (Table 1).

\section{Screening of Lactic Acid Bacteria for Antimicrobial Activity}

The antimicrobial activity of LAB isolates (culture) were tested against pathogenic bacteria and spoilage bacteria are summarized in (Table 2) by using agar well diffusion assay. The diameters of the inhibition zones were varied and ranged between 3,0 to $15,0 \mathrm{~mm}$. In general, LAB had inhibitory activity againts pathogenic bacteria and spoilage bacteria. Strain $\mathrm{BksC24}$ had the highest diameter of inhibition zones $(15 \mathrm{~mm})$. This revealed that the LAB inhibited all the pathogenic bacteria and spoilage bacteria tested. The activity of LAB culture as inhibitory to bacterial pathogens and spoilage bacteria is supported by the acid and the components of metabolites produced. Acid produced by lactic acid bacteria have the effect of antimicrobial against enteric pathogens (Daeschel, 1989). In addition to producing acid, LAB also produce other compounds inhibiting such as diasetyl, hydrogen peroxide and some strains produce bacteriocins.

According to Schillinger and Lucke (1989) inhibition was scored positive if the width of the clear zone around the colonies of the producer strain was $0.5 \mathrm{~mm}$ or larger. Similar study was carried out in Morocco by Kalalou (2004) whose studied the activity of $\mathrm{LAB}$ on some Gram positive and negative pathogenic bacteria such as Eschericia coli, Pseudomonas aeroginosa, Klebsiella pneumoniae, Staphylococcus aureus and Bacillus cereus and the inhibition zones were in the range of 1.4 to $2.8 \mathrm{~cm}$.

Many studies were carried out in Nigeria, using poultry meat to isolate LAB and study its antimicrobial activity against several microorganisms. The results showed that LAB inhibited Staphylococcus aureus, Eschericia coli, Pseudomonas aerouginosa with the exception of Candida albicans and Proteus vulgaris (Adeskan et al., 2008).

Table 2. Average of inhibition zone of LAB culture isolated from Bakasang Sample

\begin{tabular}{ccccc}
\hline & & \multicolumn{3}{c}{ Indicator bacteria $(50 \mu \mathrm{l})$} \\
\cline { 3 - 5 } No & Isolates & $\begin{array}{c}\text { E.coli } \\
(\mathrm{mm})\end{array}$ & $\begin{array}{c}\text { S.aureus } \\
(\mathrm{mm})\end{array}$ & $\begin{array}{c}\text { P.fluorescens } \\
(\mathrm{mm})\end{array}$ \\
\hline 1. & BksC1 & 11,5 & 6,0 & 6,0 \\
2. & BksC2 & 8,0 & 9,0 & 9,0 \\
3. & BksC3 & 11,0 & 9,0 & 13,0 \\
4. & BksC4 & 5,0 & 11,0 & 5,5 \\
5. & BksC5 & 7,0 & 8,0 & 6,5 \\
6. & BksC6 & 8.5 & 5,0 & 9,5 \\
7. & BksC7 & 7,0 & 8,0 & 5,5 \\
8. & BksC8 & 6,0 & 7,0 & 7,0 \\
9. & BksC9 & 10,0 & 6,5 & 12,0 \\
10. & BksC10 & 7,0 & 9,0 & 9,0 \\
11. & BksC11 & 9,0 & 7,5 & 11,5 \\
12. & BksC12 & 7,0 & - & 9,0 \\
13. & BksC13 & 8,0 & 9,0 & 9,0 \\
14. & BksC14 & 6,0 & 7,0 & 6,0 \\
15. & BksC15 & 5,0 & 6,0 & 7,0 \\
16. & BksC16 & 8,0 & 7,0 & 8,0 \\
17. & BksC17 & 7,5 & 8,0 & 8,0 \\
18. & BksC18 & 6,0 & 6,0 & 5,0 \\
19. & BksC19 & 7,5 & 8,0 & 6,0 \\
20. & BksC20 & 7.0 & 7.0 & 9,0 \\
21. & BksC21 & 5,0 & 7,0 & 5,0 \\
22. & BksC22 & 3,0 & 3,0 & 3,0 \\
23. & BksC23 & 7,0 & 8,0 & 7,0 \\
24. & BksC24 & 9,0 & 14,0 & $\mathbf{1 5 , 0}$ \\
25. & BksC25 & 7,5 & 11,0 & 7,0 \\
26. & BksC26 & - & - & - \\
27. & BksC27 & 9.0 & 9.0 & 8,0 \\
\hline & & & & \\
\hline
\end{tabular}

[-] negative activity

Generally the antimicrobial components produced by LAB inhibited the growth of Gram positive and Gram negative bacteria (De Vuyst and Vandamme ,1994) and the same was reported by Rahayu et al (1996). The activity of inhibition varies by LAB due to a combination of many factors produced, including the production of lactic acid which reduce $\mathrm{pH}$ of bakasang and also other inhibitory substances such as bacteriocins which are responsible for the most antimicrobial activity (Ogunbanwo, 2005). 
Table 3. Phenotypic characteristics of the antimicrobial-producing LAB from Bakasang Sample

\begin{tabular}{|c|c|c|c|}
\hline Characteristic & $\begin{array}{c}\text { P.acidilactici FNCC } \\
0110\end{array}$ & $\begin{array}{c}\text { P.pentosaceus FNCC } \\
0019\end{array}$ & $\mathrm{BksC} 24$ \\
\hline Gram stain & + & + & + \\
\hline Shape & Cocci & Cocci & Cocci \\
\hline Cell arrangement & Tetrad & Tetrad & Tetrad \\
\hline Production gas from glucose & - & - & - \\
\hline Catalase & - & - & - \\
\hline Spore formation & - & - & - \\
\hline Motility & - & - & - \\
\hline Fermentation type & Homo & Homo & Homo \\
\hline \multicolumn{4}{|l|}{ Growth on: } \\
\hline$-10^{\circ} \mathrm{C}$ & + & + & + \\
\hline$-\quad 40^{\circ} \mathrm{C}$ & + & + & + \\
\hline$-\quad 45^{\circ} \mathrm{C}$ & + & + & + \\
\hline$-\quad 50^{\circ} \mathrm{C}$ & + & - & + \\
\hline \multicolumn{4}{|l|}{ Growth on: } \\
\hline - $\quad \mathrm{pH} 4,5$ & + & + & + \\
\hline - $\quad \mathrm{pH} 8,0$ & + & + & + \\
\hline - $\quad$ pH 9,0 & + & + & + \\
\hline \multicolumn{4}{|l|}{ Growth on: } \\
\hline$-\quad 6,5 \% \mathrm{NaCl}$ & + & + & + \\
\hline$-\quad 10 \% \mathrm{NaCl}$ & + & + & + \\
\hline$-\quad 18 \% \mathrm{NaCl}$ & - & - & - \\
\hline
\end{tabular}

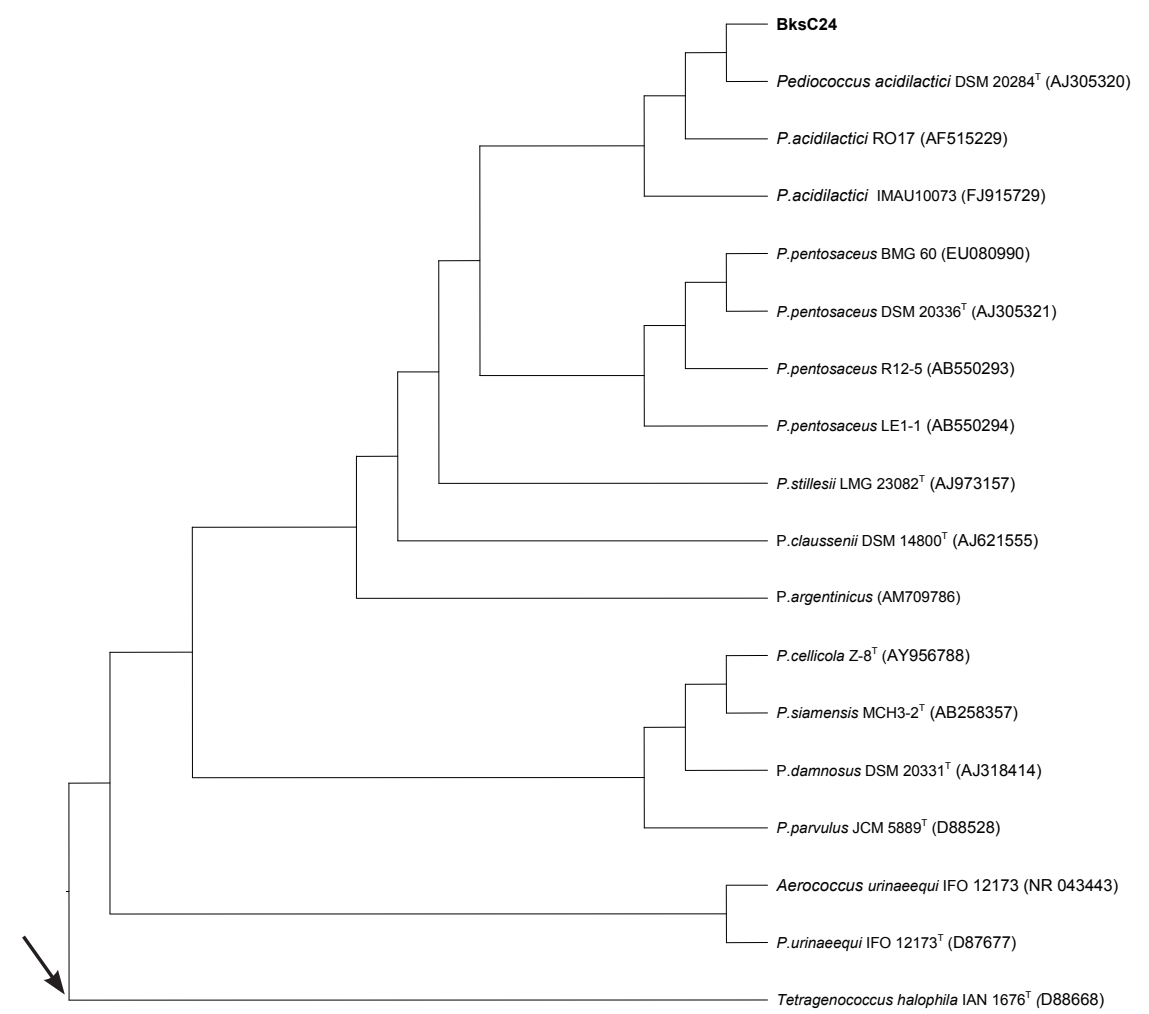

Figure 1. Phylogenetic tree showing the relationship between strain $\mathrm{BksC} 24$ and representatives of the genus Pediococcus based on $16 \mathrm{~S}$ rDNA sequences. The scale bar indicates 10 nucleotide substitution per 100 nucleotides in $16 \mathrm{~S}$ rRNA gene sequences. 


\section{Identification of Strain BksC24}

Identification of strain $\mathrm{BksC} 24$ which has highest antimicrobial activity was done based on phenotypic and genotypic characterization. The phenotypic properties of strain BksC24 is summarized in Table 3. From the morphological examination, $\mathrm{BksC} 24$ strain which has highest antimicrobial activity was Gram positive and coccus (tetrad). The isolate was catalase negative, facultative anaerobes, negative to the production of gas from glucose, non endospora forming, and non motil. Based on these characteristics, the isolate was phenotypically identified as member of Genus Pediococcus (Holt et al., 1994). Genotypic characterization was carried out to identify strain BksC24 based on 16S rRNA gene sequence comparison (Petti et al., 2005). Phylogenetic analysis demonstrated that BksC24 isolate aligned most closely with Pediococcus acidilactici DSM 20284 (GeneBank) (Figure 1). The 16S rRNA gene sequencing identified the isolate $\mathrm{BksC} 24$ as Pediococcus acidilactici $(98.79 \%$ similarity compared to the type strain of species Pediococcus acidilactici DSM 20284 in GenBank).

In conclusion, a new strain, Pediococcus acidilactici $\mathrm{BksC} 24$ which was isolated from Bakasang had the highest ability to produce antimicrobial compound inhibiting the growth of pathogenic bacteria and spoilage bacteria.

\section{References}

Adeskan A, Odetoyinbo, B and Olubamiwa AO. 2008. Biopreservative activity of lactic acid bacteria on suya produced from poultry meat. Afr. J. Biotech., 7, 3799-3808

Daeschel, M.A. 1989. Antimicrobial Substances from Lactic Acid Bacteria for Use as Food Preservatives. Food Techn., 43(1), 164-167.

Davidson, P.M and Parish, M.E. 1989. Methods for Testing The Efficacy of Food Antimicrobials, Food Tech., 148-155.

De Vuyst, L. and E. J. Vandamme. 1994. Antimicrobial Potensial of Lactic Acid Bacteria. In L. De Vuyst. Dan E. J.
Vandamme (eds.). Bacteriocins of Lactic Acid Bacteria Microbiology, Genetics and Applications. Blackie Academic and Professional, London.

Dykes, G.A., Britz, T.J., von Holy, A., 1994. Numerical taxonomy and identification of lactic acid bacteria from spoiled, vacuum packaged Vienna sausages. Jour. App. Bacteriol., 76, 246- 252.

Holt J.G., Krieg N.R., Sneath, P.H.,Stanley, J.T. and Williams, S.T. 1994. Bergey`s Manual of Determinative Bacteriology. Ninth Edition. Williams and Wilkins. USA.

Kalalou I, Faid M and Ahami AT. 2004. Extending shelf life of fresh minced camel meat at ambient temperature by Lactobacillus dlbrueckii subsp. delbrueckii. Electronic Jour. Biotech., 7 (3), 1-6.

Liasi, S. A., Azmi, T. I., Hassan, M. D., Shuhaimi, M., Rosfarizan, M.1 and Ariff, A. B. 2009. Antimicrobial activity and antibiotic sensitivity of three isolates of lactic acid bacteria from fermented fish product, Budu. Malay. Jour. Microbiol., Vol 5(1), 33-37.

Ogunbanwo S.T. 2005. Functional properties of lactic acid bacterial isolated from ogi and fufu, Two Nigerian fermented foods. J. Food Sci., 27, 14-21.

Ouwehand, A.C. 1998. Antimicrobial Component from Lactic Acid Bacteria. In). Lactic Acid Bacteria, Microbiologi and Functional Aspect, S.Salminen \& A. Von Wright, Eds. Sec Edition. Marcel Dekker, Inc. New York.

Park, Jong-Hwan., Seung-Hyeok Seok ., Sun-A Cho., Min-Won Baek., HuiYoung Lee., Dong-Jae Kim., Myung-June Chung.,Soo-Dong Kim., Un-Pyo Hong and Jae-Hak Park. 2005. Antimicrobial effect of lactic acid producing bacteria culture condensate mixture (LCCM) against Salmonella enteritidis. Intl. Jour. Food Microbiol., 101 (1), 111-117.

Panthavee, W., Pramuan, S and Nisakornn W. 2007. Identification and Evaluation of Lactic Acid Bacteria for Pla- 
Som (Fermented Fish) Starter. The $2^{\text {nd }}$ International Conference on "Fermentation Technology For Value Added Agricultural Products" May 23-25, at Kosahotel, Kohn-Kaen, Thailand.

Petti, C.A., Polage, C.R and Schreckenberger, P. 2005. The Role of 16 S rRNA Gene Sequencing in Identification of Microorganisms Misidentified by Conventional Methods. Jour. Clin. Microbiol., 43 (12), 6123-6125.

Pospiech, A and Neumann, B. 1995. A. Versatile Quick-prep of Genomic DNA from Gram Positive Bacteria. Trends Gen., 11, 217-218.

Rahayu, E.S., Djaafar T.F., Djoko W., and Sudarmadji., 1996. Lactic Acid Bacteria from Indigenous Fermented Foods and Their Antimicrobial Activity. Indo. Food and Nutr. Progress, 3(2), 21-28.

Saitou, N and M. Nei., 1987. The Neighbourjoining Method : A New Method for Reconstruction Phylogenetic Trees. Mol. Biol. Evol., 4, 406-426

Savadogo, A., Cheik A.T. Ouattara, Imael. H.N. Bassole, Alfred S. Traore. 2004. Antimicrobial Activities of Lactic Acid Bacteria Strains Isolated from Burkina Faso Fermented Milk. Pakist. Jour. Nutr., 3(3), 174-179.

Schillinger U, and LuckeF.1989. Antimicrobial activity of Lactobacillus sake isolated from meat. J.Appl. Environ. Microbiol., 55,1901-1906.

Thomas, P. 2007. Isolation and Identification of Five Alcohol-defying Bacillus spp. Covertly Associated with In Vitro Culture of Seedless Watermelon. Curr. Sci., 92(7), 983-986.

Thompson, J.D. Gibson, T.J. Plewniak, F., Jeanmougin,F. and Higgind, D.G. 1997. The ClustalX Windows Interface:flexible strategies for multiple sequence alignment aided by quality tool. Nucl. Ac. Res., 24 , 4876-4882. 